\title{
搽 PRIMENA AUTOMATIZACIJA IZVEŠTAVANJA U ANALIZI POSLOVNIH SISTEMA - VEB PLATFORMA KAO ALAT ZA START-UP KOMPANIJE
}

\author{
Nikola Pavlović* \\ Visoka škola strukovnih studija za informacione tehnologije, Beograd \\ Velimir Dedic ${ }^{* *}$ \\ Fakultet za informacione tehnologije i inženjerstvo, Beograd \\ Marko Ranković ${ }^{* * *}$, Milena llić**** \\ Visoka škola strukovnih studija za informacione tehnologije, Beograd
}

start-up kompanijama koje su počele sa jako malo resursa („od nule") često ne postoji dovoljno početnog kapitala da bi se pribavili svi potrebni resursi i obezbedila dobra startna pozicija na tržištu. Stoga, start-up kompanije koje bi se bavile konsultantskim uslugama, sa potrebnim znanjem koje poseduju, mogu obezbediti konkurentsku prednost jednostavnom automatizacijom konsultantskih usluga primenom ove ili slične platforme.

Time dobijaju moćan alat u svojoj oblasti rada po relativno pristupačnoj ceni u zavisnosti od iskustva tima i njegovog sastava. S obzirom da su mladi sve više uključeni u oblast informacionih tehnologija bilo kojim poslom da se bave i da je učenje programiranja sve dostupnije na internetu, start-up kompanije veštine zaposlenih mogu iskoristiti uz minimalna ulaganja da bi oformili platformu.

Ključne reči: automatizacija, izveštavanje, start-up, veb platforma

\section{Uvod}

U radu je predstavljena aplikacija koja omogućava analizu poslovnog sistema po određenim prostornim oblastima, različitim modulima koji objedinjuju više prostornih oblasti i kompletnu organizaciju. Aplikacija radi na bazi anketiranja zaposlenih elektronskim putem bez otkrivanja i beleženja njihovog identiteta, ali uz potvrdu identiteta svojim poslovnim mejlom. Aplikacija je kreirana uz pomoć Google Forms servisa u integraciji sa lokalnom bazom podataka na serveru kako bi bili dostupni podaci za obradu. $U$

\footnotetext{
* Inženjer organizacionih nauka, nikola.pavlovic@its.edu.rs

${ }^{* *}$ Redovni profesor, doktor tehničkih nauka, velimir.dedic@fpsp.edu.rs

*** Docent, doktor organizacionih nauka, marko.rankovic@its.edu.rs

**** Docent, doktor ekonomskih nauka, milena.ilic@its.edu.rs
} 
cilju obezbeđenja izmena i upravljanje samom aplikacijom u WordPress-u je izrađeno $\mathrm{CMS}^{1}$ okruženje a back-end ${ }^{2}$ deo sajta pokreće $P H P$.

U izradi rešenja korišćene su i Google-ove aplikacije poput Forms i Sheets; da bi se omogućila komunikacija između njih i baze podataka potreban je Google Scripts kao Java server-side script jezik zadužen za transfer odgovora iz Google Sheets-a u MySQL bazu na serveru.

\section{Pregled literature}

U 21. veku kompanije će zameniti opise poslova sa modelima kompetentnosti kao što su (Ranković \& llić, 2018): Naučna/tehnička umeća, veštine liderstva i veštine procesiranja.

Upravo o tome govori i koncept organizacionog dizajna kojem su menadžeri počeli da posvećuju sve više pažnje. Organizacioni dizajn se ogleda u tehnikama projektovanja organizacije i njene strukture. Tradicionalni oblici organizacija su i dalje prisutni a novi zapravo kombinuju prednosti već postojećih oblika i manje modifikacije radi fleksibilnosti i lakše skalabilnosti organizacije (Burton, Obel, \& DeSanctis, 2011).

Razlika između klasične i savremene poslovne organizacije vidi se samo u tome gde je težište - na kojoj strani od dve krajnje tačke karakteristične za sva organizaciona načela (Sajfet, 2006). Da li se težište usmerava na tradicionalne vrednosti i hijerarhiju ili na težište prema potrebama tržišta i kupaca.

Svaki informacioni sistem se koristi kao podrška u donošenju odluka, olakšavajući svojom upotrebom određeni proces rada. Međutim, svaki za sebe se upotrebljava za drugačiju strukturu problema i prirode odluke.

Postoji više načina za planiranje i implementaciju automatizacije. Pojedine organizacije biraju da prvo implementiraju međusobno povezane i potrebne sisteme a zatim da analiziraju njihove uobičajene probleme i identifikuju događaje koji mogu biti iskorišćeni kao okidač za automatizovanu akciju. Druge pak odlučuju da automatizuju procese istovremeno kada rade na analizi problema međusobno povezanih sistema (Zohuri \& Moghaddam, 2017).

Informacione i komunikacione tehnologije se razvijaju veoma brzo, menjajući značajno pristup svim sferama ekonomije (Popkova \& Ostrovskaya, 2019). Time automatizacija dobija sve značajniju ulogu u globalnoj ekonomiji i svakodnevnom poslovanju.

Podatak koji čini informaciju mnogo vredi. Kako su se razvile informaciono-komunikacione tehnologije tempo rada se umnogome promenio. Danas da bi bili uspešni moramo biti spremni i na prekovremeni rad koji utiče u mnogome na naše aktivnosti, aktivnosti celog ljudskog društva, njegovog razvoja kao i kvaliteta života (Pokorni \& Radić, 2013)

Proces analize same organizacije nije jednostavan i zahteva dosta vremena u zavisnosti od obima analize i stručnosti onoga ko vrši analizu. Proces analize se definiše kao pažljiva studija nekog predmeta sa ciljem da se steknu znanja o njegovim delovima, čemu služe i kako su međusobno povezani (Merriam-Webster 2015) (Meisen, 2016).

\footnotetext{
${ }^{1} \mathrm{CMS}$ - Content Management System je engleski termin za sistem dinamičnog upravljanja sadržajem i predstavlja modularnu web platformu poput WordPress, Joomla i sličnih. Koristi se radi lakšeg i jednostavnijeg unošenja izmena sadržaja u okviru web prezentacija.

${ }^{2}$ Back-end predstavlja pogled na softver koji se bavi načinom pristupa i obradom podataka.
} 


\section{Veb platforma}

Da bi znali u kakvom stanju je trenutno poslovna organizacija to se može učiniti na dva načina:

1. Angažovanjem organizacije koja pruža konsultantske usluge u oblasti analize poslovnih sistema

2. Angažovanjem zaposlenih unutar firme koji su obučeni za analizu poslovnih sistema.

Prva opcija iziskuje finansijska sredstva za pružene usluge i može varirati u zavisnosti od veličine naše organizacije i njene kompleksnosti kao i kompleksnosti procedura rada. Potrebno je da konsultant, u zavisnosti od prirode posla i veličine poverenih zadataka, provede odgovarajuće vreme u firmi koje je obično od 10 do 30 dana i za to vreme prati rad svakog sektora u organizaciji. Sve zaključke do kojih dođe zapisuje po određenom formularu a takođe zaposlenima daje posebno pripremljena pitanja na koja odgovaraju, u većini slučajeva, anonimno. Nakon prikupljenih podataka sledi analiza nakon koje se dobija izveštaj u papirnoj ili elektronskoj formi o stanju organizacije i predložene izmene radi poboljšanja stanja.

Ovde takođe postoji i faktor poverenja kao i sporazum i potpisivanje dokumenta o poverljivosti podataka do kojih konsultant dođe prilikom vršenja usluge. Zatim kvalitet izvršenih usluga i utrošeno vreme za realizaciju.

Druga opcija takođe iziskuje finansijska sredstva ali može biti isplativija ako kompanija ima zaposlene koji mogu biti obučeni za analizu organizacije. Zaposleni mogu biti poslati na eksternu obuku ili to uraditi interno. Kada uspešno prođu obuku u stanju su da analiziraju organizaciju i na duži period mogu češće vršiti analizu a time i uštedeti na čestom plaćanju konsultantskih usluga sa strane.

Najbitnija stvar je da osoba koja vrši analizu bude potpuno objektivna, radi relevantnih rezultata. Shodno tome cilj i jeste obrađivati podatke na način da se ne može prepoznati o kom zaposlenom se tačno radi. Ako se analiza radi na papiru, sasvim je moguće da osoba koja vrši analizu može prepoznati ko je u pitanju na osnovu rukopisa. Analiza u elektronskoj formi podrazumeva popunjavanje ankete bez zabeleške o korisniku prilikom popunjavanja i onemogućavanja jednostavnog uvida ko je kada popunio anketu i sa kojim odgovorima.

Kada uzmemo sve u obzir došlo se do ideje o automatizaciji čitavog procesa analize jednog poslovnog sistema i generisanja izveštaja u elektronskoj formi. To je moguće uz pomoć aplikacije koja može biti projektovana na više načina, a za potrebe ovog rada je urađena web aplikacija (platforma) na internet adresi _(Pavlović, 2019).

Aplikacija omogućava analizu poslovnog sistema po određenim prostornim oblastima, različitim modulima koji objedinjuju više prostornih oblasti i kompletnu organizaciju. Princip rada same aplikacije se zasniva na anketiranju zaposlenih elektronskim putem, anonimno, ali uz potvrdu identiteta svojim poslovnim mejlom. Sama aplikacija je sastavljena pomoću Google Forms servisa u integraciji sa lokalnom bazom podataka na serveru radi dostupnosti podataka za obradu. 


\section{Funkcionalnosti platforme}

U nastavku rada biće opisano koje funkcionalnosti platforma poseduje i na koji način su upotrebljeni servisi u njenoj izradi.

Aplikaciji se pristupa preko već pomenute adrese a admin panelu za upravljanje izveštajima i anketama preko standardnog linka za pristup WordPress admin panelu radi jednostavnosti - . Nakon logovanja određenim korisničkim nalogom dobijamo prozor kao na slici 1.

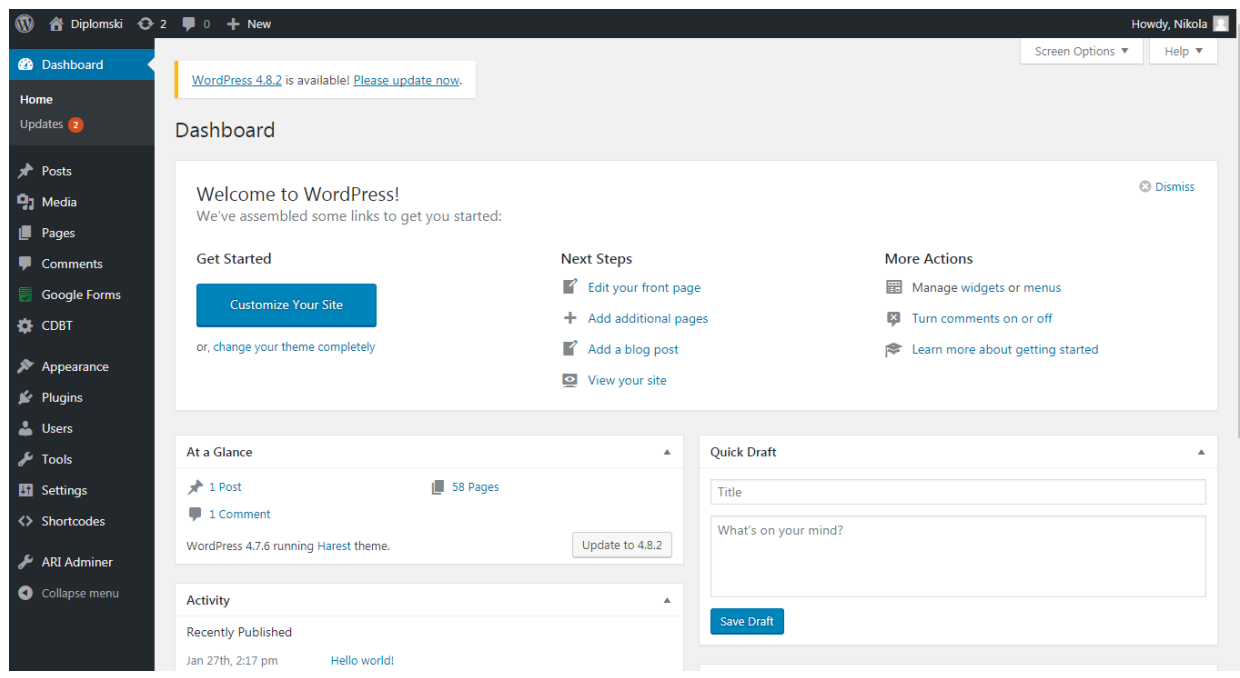

Slika 1 - Admin Panel

U admin panelu je moguće dodavati nove ankete sa Google naloga zaposlenog, vršiti analizu odgovora, dodavanje generičkih rezultata ankete kao i slanje e-mail izveštaja sa rezultatima istraživanja.

Na slici 2 može se uočiti više različitih celina kao i opcija izbora u samom admin panelu aplikacije:

1. Glavni prozor gde se izlistavaju sve opcije za podešavanja, pregled i kreiranje stranica, formulara i sl.

2. Dashboard - Sumarni prikaz stanja web aplikacije koji može biti podešen po želji korisnika radi što bržeg pregleda određenih informacija.

3. Media - Opcija za unos multimedijalnih sadržaja poput slika, video materijala i dokumenata.

4. Pages - Pregled, kreiranje novih i izmena postojećih web stranica.

5. Google Forms - Ubacivanje novih anketa i izmena već postojećih.

6. CDBT - Dodatak koji je naknadno ubačen kao opcija za konekciju sa bazom podataka i operacijama nad podacima. 
7. Appearance - Podešavanje izgleda platforme i stilizacija izgleda menija.

8. Plugins - Dodaci koji omogućuju dodatne opcije na platformi bez kodiranja.

9. Users - Pregled korisnika i dodela uloga.

10. ARI adminer - Dodatak koji je naknadno ubačen za rad nad podacima u bazi podataka.

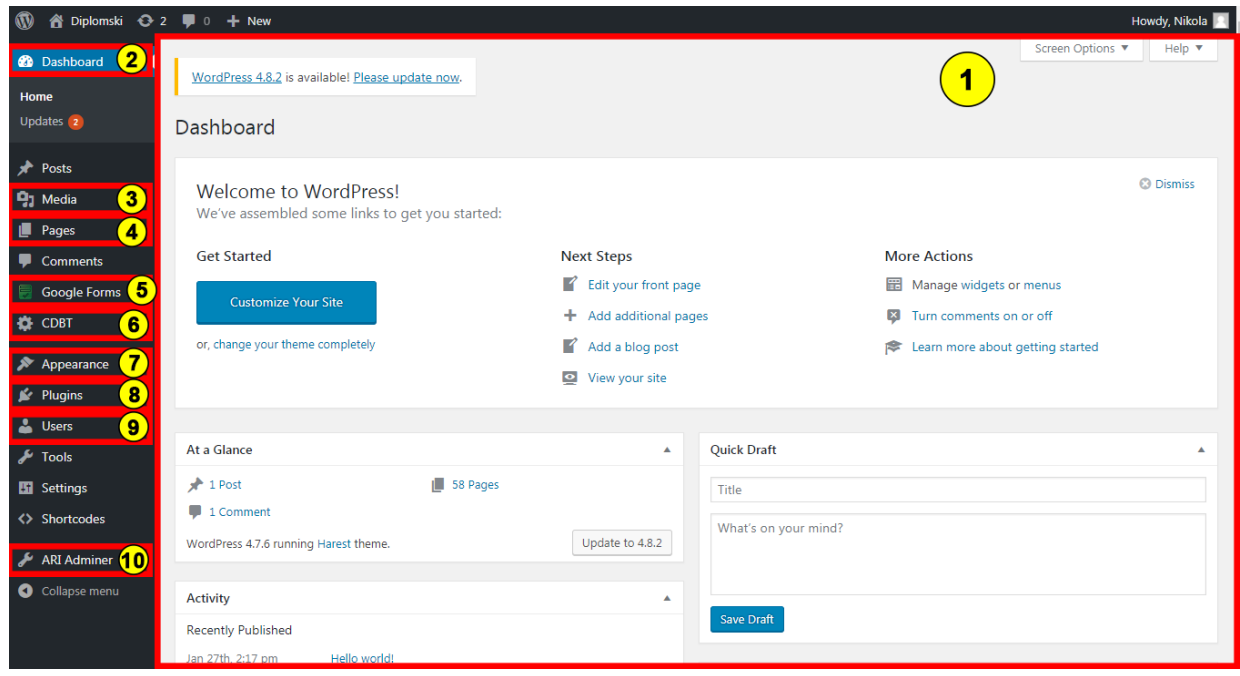

Slika 2 - Delovi admin panela

Sam admin panel je moguće lako prilagoditi zbog same prirode WordPress platforme uz pomoć takozvanih plugin-ova ${ }^{3}$ koji aplikaciji dodaju određenu funkcionalnost. Pomoću njih je moguće uz minimalno programersko znanje napraviti modularnu platformu za različite potrebe.

Plugin-ovi koji su korišćeni u izradi aplikacije su:

- ARI Adminer

- Custom DataBase Tables

- Google Forms

- Page Links To

- PHP Everywhere

- Shortcodes Ultimate

- WP User Manager

i prikazani su na slici 3.

\footnotetext{
${ }^{3}$ Plugin - gotovo softversko rešenje (modul) koji je moguće integrisati u određeni CMS sistem.
} 


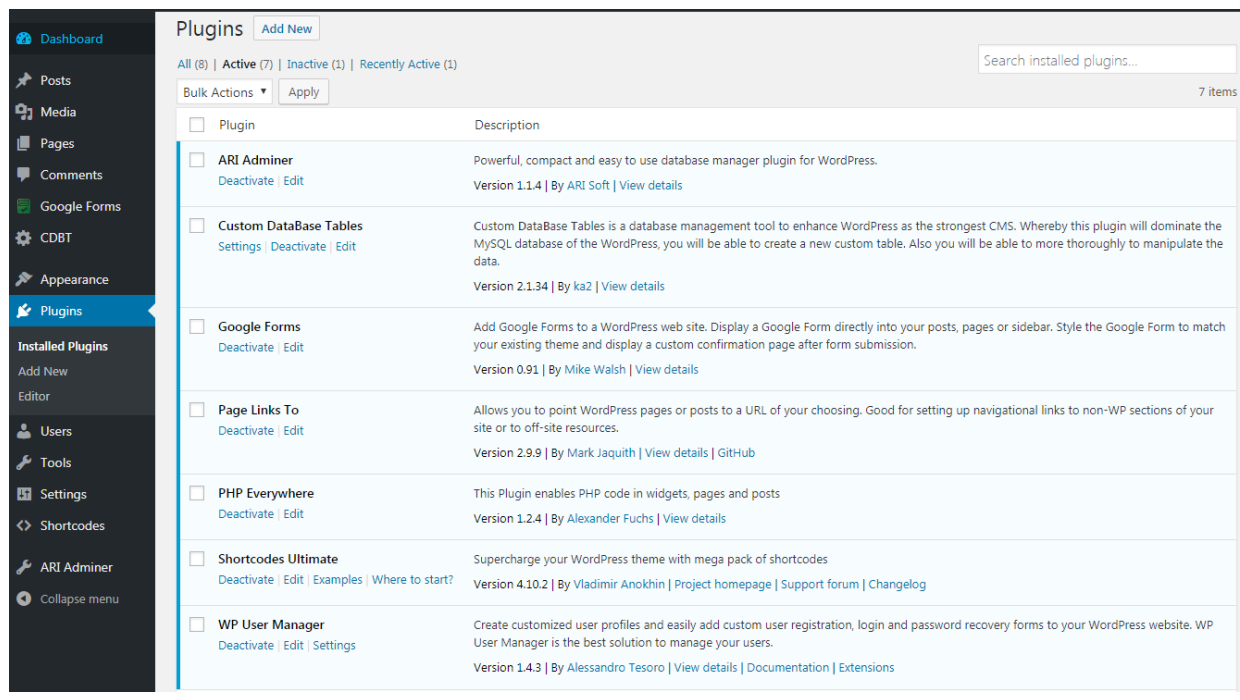

Slika 3 - Plugin-ovi korišćeni za izradu aplikacije

ARI adminer i CDBT (Custom DataBase Tables) su zapravo dva identična plugin-a. Imaju istu namenu, a to su operacije nad podacima u bazi podataka. Na korisniku je ostavljen izbor koji od ova dva će koristiti.

Oba plugin-a imaju sličan interfejs PhpMyAdmin ${ }^{4}$ panelu koji se koristi kao standardni program za operacije nad bazom podataka na serveru. Izgled $A R I$ adminer interfejsa može se videti na slici 4.

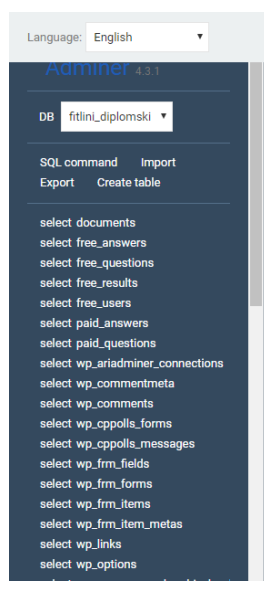

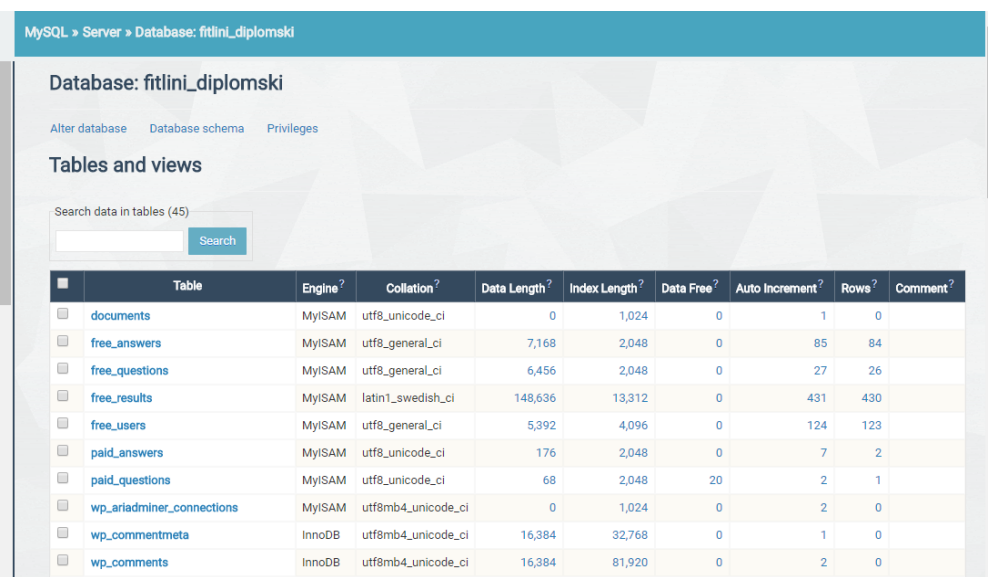

Slika 4 - ARI adminer

\footnotetext{
${ }^{4}$ PhpMyAdmin - softversko rešenje za operacije nad bazama podataka.
} 
Da bi baza podataka imala smisla i zaista bila upotrebljiva, mora sadržati tabele u sebi. Tabele su zapravo logičke celine jedne baze i služe za lakše razvrstavanje podataka i manipulaciju.

Tabele koje su kreirane za potrebe analize u ovom projektu su:

- Tabela documents - zabeležene putanje do fajlova za korisnike koji su se opredelili za plaćenu konsultantsku uslugu. Ova tabela služi kako bi fajl bio dostupan online na našem serveru i spreman za preuzimanje od strane klijenta u bilo koje doba dana putem odgovarajućeg linka koji mu je poslat u mail-u.

- Tabela free_users - služi da zabeleži posetu korisnika koji su došli na platformu kao posetioci i žele da isprobaju način na koji se vrši analiza. Ovo je namenjeno ako je rešenje komercijalizovano i objavljeno javno na internetu. Predstavlja besplatan alat za brzu procenu stanja, ali tačnost modela nije precizirana.

- Tabele free_questions i free_answers - za unos pitanja i odgovora od strane posetilaca web platforme kao komercijalnog rešenja. Na osnovu ubeleženih podataka se dobija automatizovani proračun rezultata na kraju popunjene forme.

- Tabele paid_questions i paid_answers - identično kao i prethodne dve pomenute sem što se koriste za plaćene usluge i detaljnu analizu. Tabela paid_questions se unosi ručno dok paid_answers se popunjava automatski prilikom rešavanja forme.

- Tabela free_results - sadrži automatizovane i generisane rezultate koji se prikazuju korisnicima koji dođu kao posetioci na platformu.

Google Forms se koristi za integraciju Google upitnika na sajt. Upitnici se kreiraju posebno na određenom korporativnom nalogu zaposlenog. Na slici 5 i 6 vidljiv je prikaz opcija koje poseduje ovaj dodatak. 


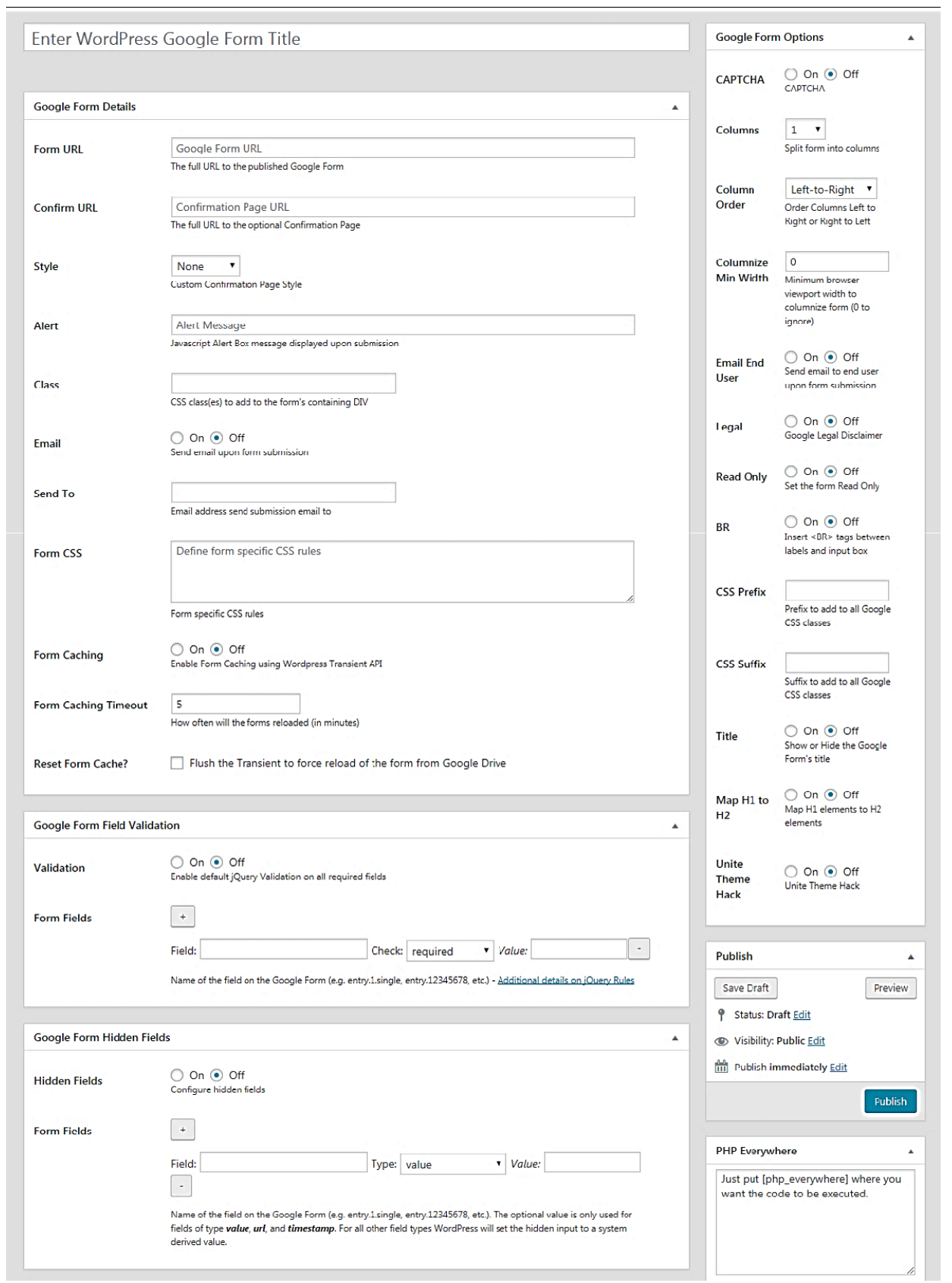

Slika 5-Google Forms - deo 1 


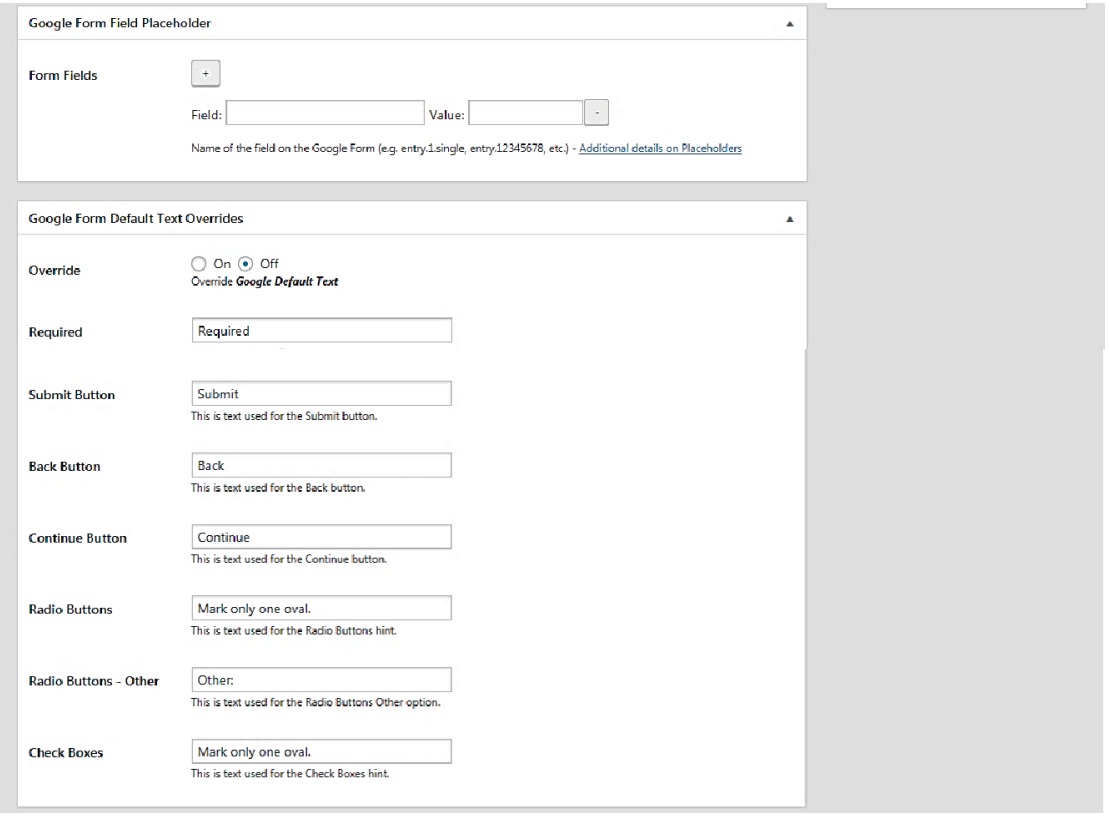

Slika 6 - Google Forms - deo 2

Nisu sva polja obavezna prilikom unošenja određene ankete na sajt. Deo njih služi za dodatnu stilizaciju forme i njen bolji prikaz u okviru platforme kao i prevenciju automatizovanih unošenja odgovora pomoću određenog softvera. Na slici 7 su prikazana poželjna polja za unos, a od toga su prva dva obavezna.

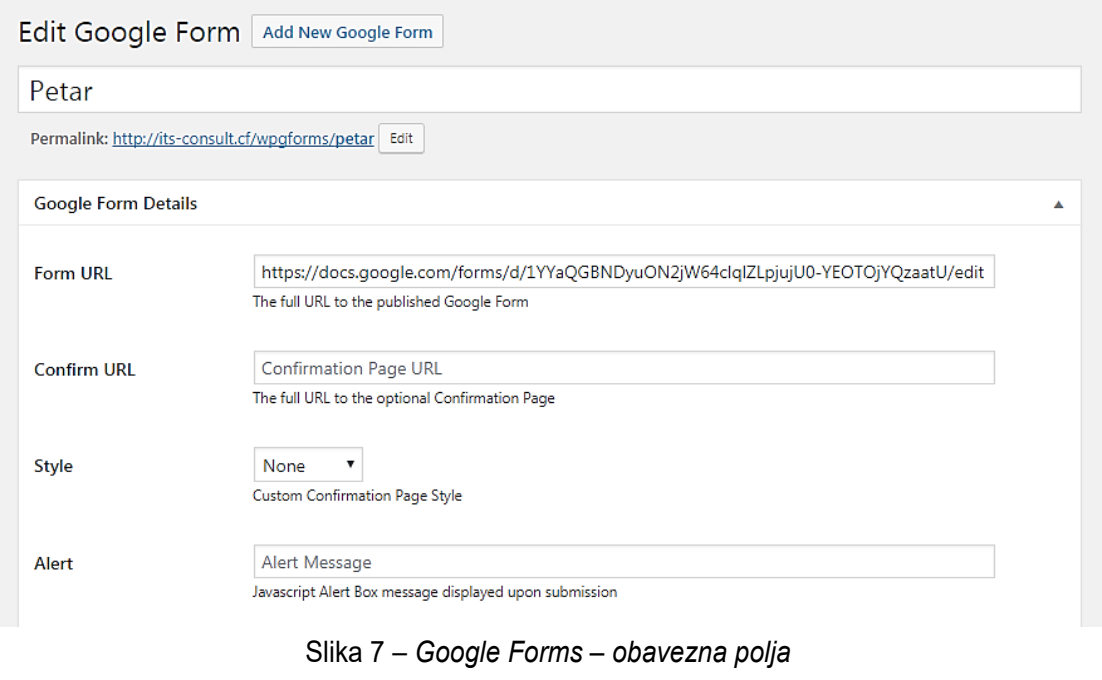


Na slici 7 su polja za popunjavanje:

1. Naziv stranice - sve Google forme imaju svoju posebnu stranicu za korisnika koja bi trebalo biti različita ako ne po imenu onda po URL adresi koja se nalazi odmah ispod $i$ koju WordPress automatski generiše. sniku.

2. Form URL - URL adresa koja vodi do forme koju želimo prikazati određenom kori-

3. Confirm URL - Ova opcija je opciona i koristimo je ako želimo da nakon završene ankete korisnik ne ostane na istoj strani i vidi samo Google-ovu „Thanks" poruku nakon popunjene forme. Tu upisujemo URL naše strane na koju će korisnik biti preusmeren nakon završetka popunjavanja svoje forme.

4. Style - opcija koja nije striktno obavezna ali se nadovezuje na prethodnu. Određuje na koji način će korisnik biti preusmeren na sledeću stranicu. Postoje tri opcije u padajućem meniju za ovu opciju i to su:

- None - Bez preusmeravanja.

- Redirect ${ }^{5}$ - Preusmeri sa ponovnim učitavanjem kompletne stranice.

- AJAX $X^{6}$ - Preusmeri bez ponovnog učitavanja cele stranice već samo okvira.

5. Alert message - Služi ako želimo da korisniku izbacimo pop-up poruku putem Javascript $^{7}$ jezika kada uspešno popuni anketu

Da bi platforma funkcionisala kao i dodatak Google Forms, moramo imati već spremljene ankete na nalogu zaposlenog. Proces kreiranja Google formi je jednostavan i intuitivan. Izgled prozora za kreiranje Google forme može se pogledati na slici 8.

\footnotetext{
${ }^{5}$ Redirect - Preusmeravanje korisnika sa trenutne web stranice na neku drugu.

${ }^{6}$ AJAX - Asynchronous JavaScript And XML, tehnika razvoja veb-aplikacija koja omogućava da se prikažu samo novi podaci na veb-stranici, a da cela veb-stranica ne mora ponovo da se učitava. Taj proces ubrzava vreme odgovora i povećava zadovoljstvo korsnika.

${ }^{7}$ Javascript - skriptni programski jezik, najčešće u upotrebi na web stranicama u svrhu interaktivnosti (akcijareakcija).
} 


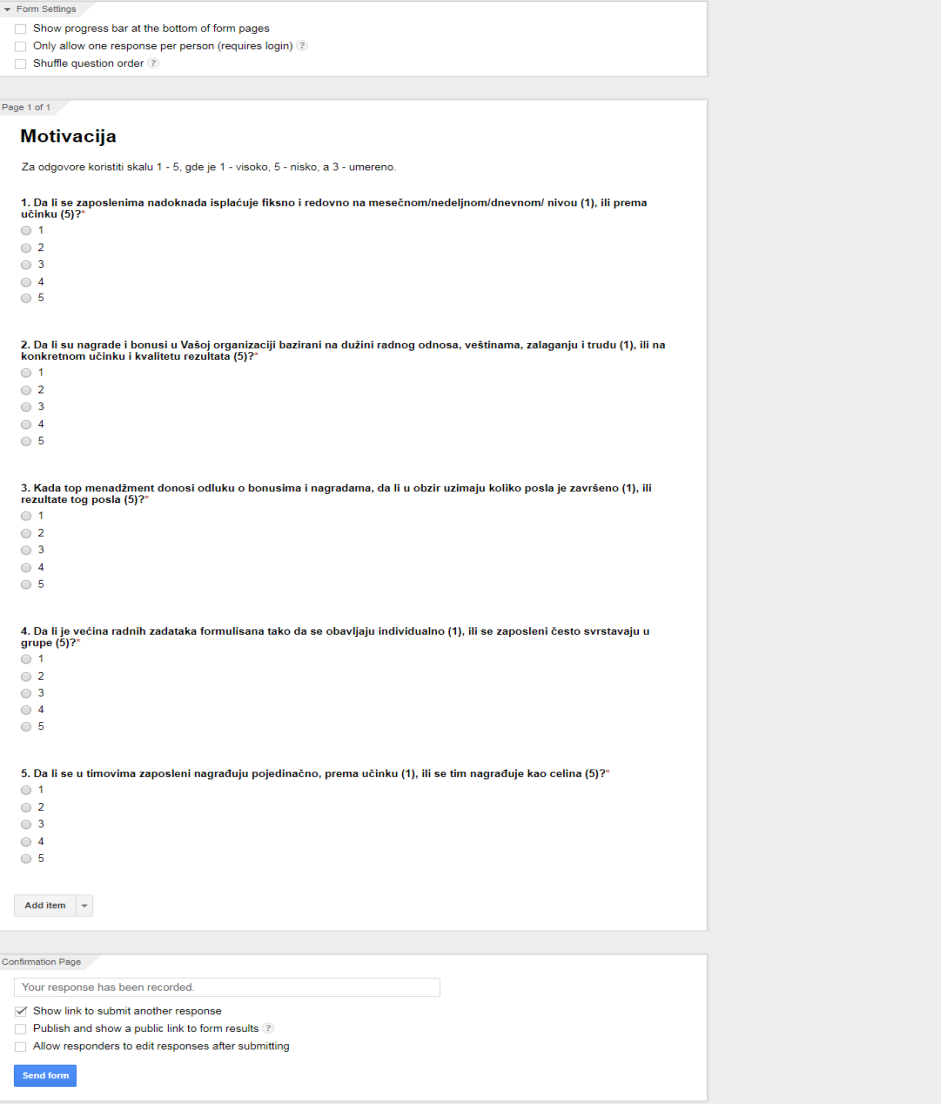

Slika 8 - Google Forms - Kreiranje

Pitanja mogu biti različitih tipova: otvorena, zatvorena, sa jednim ili više tačnih odgovora a mogu sadržati i dodatni multimedijalni sadržaj poput slika, video materijala ili lista sa izborom. Takođe, moguće je podesiti šta će se nalaziti na stranici potvrde, pozdravnu poruku i dodatne opcije poput mešanja pitanja i ograničenja popunjavanja samo jednom po jednom korisniku.

Svi odgovori iz forme se beleže u odgovarajuću Google Sheets tabelu. Da bi mogli da vršimo manipulaciju podacima u sigurnom okruženju napisana je skripta pomoću Google Script jezika koja omogućava transfer zabeleženih podataka iz Google Sheets tabele u bazu podataka na našem serveru. Skripta je primenjivana na svaku Google Sheets tabelu vezanu za odgovarajuću formu.

Kada se podaci ubeleže u lokalnu bazu podataka moguće je napisati dodatne skripte za proveru odgovora i generisanje automatskog izveštaja kao i proveru korisnika koji pristupa anketi u plaćenoj verziji. 
Page Links to plugin je dodatak koji omogućava jednostavno preusmeravanje stranica na drugu adresu. U konkretnoj upotrebi u ovom projektu služi za preusmeravanje određenih stranica na dodatne PHP skripte ${ }^{8}$ koje su napisane radi dodatne validacije korisnika i za izbor odgovarajućeg upitnika za ulogovanog korisnika.

Dodatne PHP skripte su neophodne u procesu izrade platforme. lako je WordPress CMS platforma modularna i postoji veliki broj predefinisanih plugin-a kojima se mogu kreirati razna rešenja, pojedine operacije nije moguće predvideti i generički izraditi da budu primenljive u svakoj situaciji.

Konkretne skripte koje su pisane za ovu platformu, su:

1. connect.php - Pozivana je za korišćenje u sklopu ostalih skripti da bi imale pristup bazi podataka. Sadrži podatke o imenu baze podataka, adresi na kojoj se nalazi kao i korisničkom imenu i šifri kojom se pristupa bazi podataka.

2. GetInfoAndForm.php - Koristi se u brzoj besplatnoj proceni stanja analize nakon što korisnik odabere željenu oblast analize. Nakon odabira oblasti skripta pretražuje odgovarajuće ankete i bira jednu od više njih nasumičnom metodom, zatim informacije o odabiru smešta u bazu i prosleđuje korisnika na stranicu sa anketom.

3. GetUserAndLogIn.php - Služi za ponovnu autentifikaciju korisnika prilikom logovanja ili dužeg vremena neaktivnosti radi potvrde identiteta. Koristi se za plaćeni deo platforme o kome će biti više reči u nastavku rada.

4. GoToForm.php - Nakon uspešnog logovanja korisnika u plaćenoj verziji, ova skripta vrši pretragu baze za određenom anketom koja je namenjena korisniku. Nakon uspešne pretrage ga preusmerava na stranicu za izradu ankete a u slučaju pokušaja da se uloguje korisnik kome anketa sa prethodno dostavljenog linka nije namenjena dobija informaciju da mu je pristup zabranjen. U slučaju da nema aktivnih anketa za rešavanje ispisuje se adekvatna poruka.

5. GetResults.php - Skripta je pisana za potrebe izračunavanja automatske analize odgovora. Funkcioniše na način tako što se konektuje na bazu podataka nakon što su podaci o odgovorima trenutnog korisnika upisani u bazu. Uzima podatke o odgovorima korisnika kao i podatak koja je anketa rađena i prema formuli za određenu anketu se vrši izračunavanje rezultata. Nakon toga se rezultat prosleđuje stranici za prikaz rezultata.

PHP Everywhere plugin omogućuje izvršavanje PHP koda u okviru definisane stranice platforme. Ukoliko sama platforma ne poseduje neku određenu funkciju dinamičnog generisanja sadržaja, ovaj dodatak se može iskoristiti da se napiše sopstvena skripta za tu namenu. Nakon toga je dovoljno samo određeni tag ubaciti na željeno mesto na stranici i funkcija će biti izvršena prilikom učitavanja stranice.

Plugin ima konkretnu upotrebu na platformi u sklopu stranice za rezultate. Pomoću odgovarajućih kratkih kodova omogućen je ispis dinamičnog sadržaja rezultata.

Shortcode Ultimate je moćan dodatak za svaki sajt i omogućava razne funkcionalnosti umetanjem odgovarajućeg kratkog koda na stranicu. Služi za bolji raspored sadržaja u okviru stranice pomoću kolona i redova, dodaje odgovarajuća polja za multimedijalni sadržaj, animacije i slično.

WP User Manager je dodatak koji određuje koje privilegije korisnici imaju na platformi. Korišćen je u svrhu prikaza određenih elemenata u meniju za ulogovane korisnike i sakrivanje istih od posetilaca koji nisu ulogovani. Može biti koristan ako se kasnijim razvitkom platforme omogući korisniku da na svom profilu pregleda sve dosadašnje ankete koje je radio i za koju namenu.

\footnotetext{
${ }^{8}$ PHP skripte - skripte ili tačnije kod pisan u php jeziku koji se pokreće sa serverske strane.
} 


\section{Metod rada platforme}

Nakon što je objašnjen način rada same platforme sa korisničke strane onoga ko analizira, biće objašnjeno kako aplikacija funkcioniše i sa klijentske strane. Klijent zapravo dobija link putem email-a koji ga vodi do ankete ili pristupa direktno platformi. Kao što je već spomenuto, na platformi može se probati demo verziju aplikacije (brza analiza sa automatski generisanim odgovorima) ili raditi neku od plaćenih usluga. Kada korisnik pristupi svojoj anketi, rešava je i na kraju dobija pozdravnu poruku. Na slikama 9, 10 i 11 može se videti izgled aplikacije kod brze i besplatne analize.

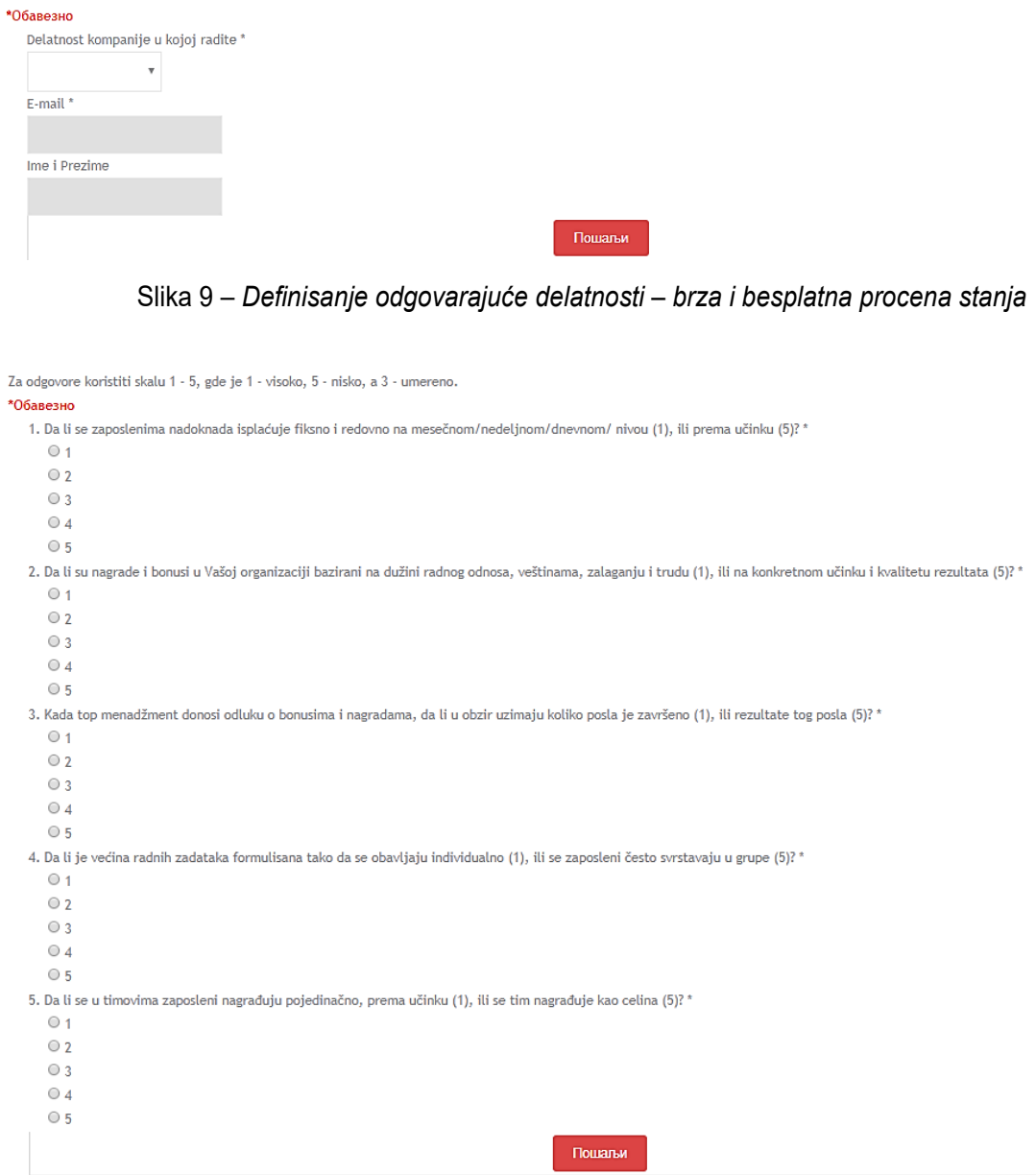

Slika 10 - Izgled ankete kod brze i besplatne procene 


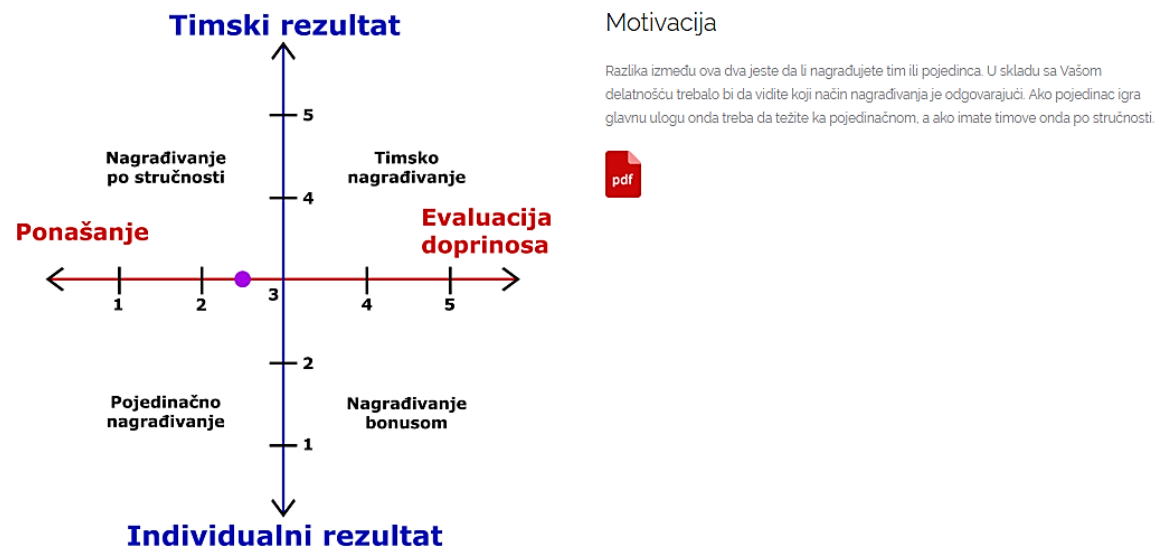

Slika 11 - Izgled stranice sa rezultatom nakon završene ankete

Na prvi pogled sve deluje jednostavno i prosto. Međutim, ono po čemu se ova platforma izdvaja od obične Google Forme za anketiranje jeste to što se oslanja na svoju sopstvenu bazu podataka i mehanizam analize iza upitnika.

$U$ besplatnoj varijanti nakon unošenja mejla i tipa delatnosti, prvo se odgovori beleže u bazu podataka a zatim se klijentu dodeljuje traženi upitnik za određenu analizu. S obzirom da je potrebno imati više različitih pitanja u sistemu da se ne bi ponavljala, klijentu će se dodeliti nasumična kombinacija odgovarajućih pitanja za izabranu oblast analize. Nakon potvrde unosa odgovora oni se smeštaju ponovo u bazu za pripadajućeg korisnika i na osnovu automatske analize se generiše predefinisani izveštaj i vraća korisniku kao rezultat. Taj rezultat je moguće preuzeti sa aplikacije i potom odštampati.

Na slikama 12 i 13 vidi se izgled aplikacije sa klijentske strane koji je registrovan (plaćena verzija). 


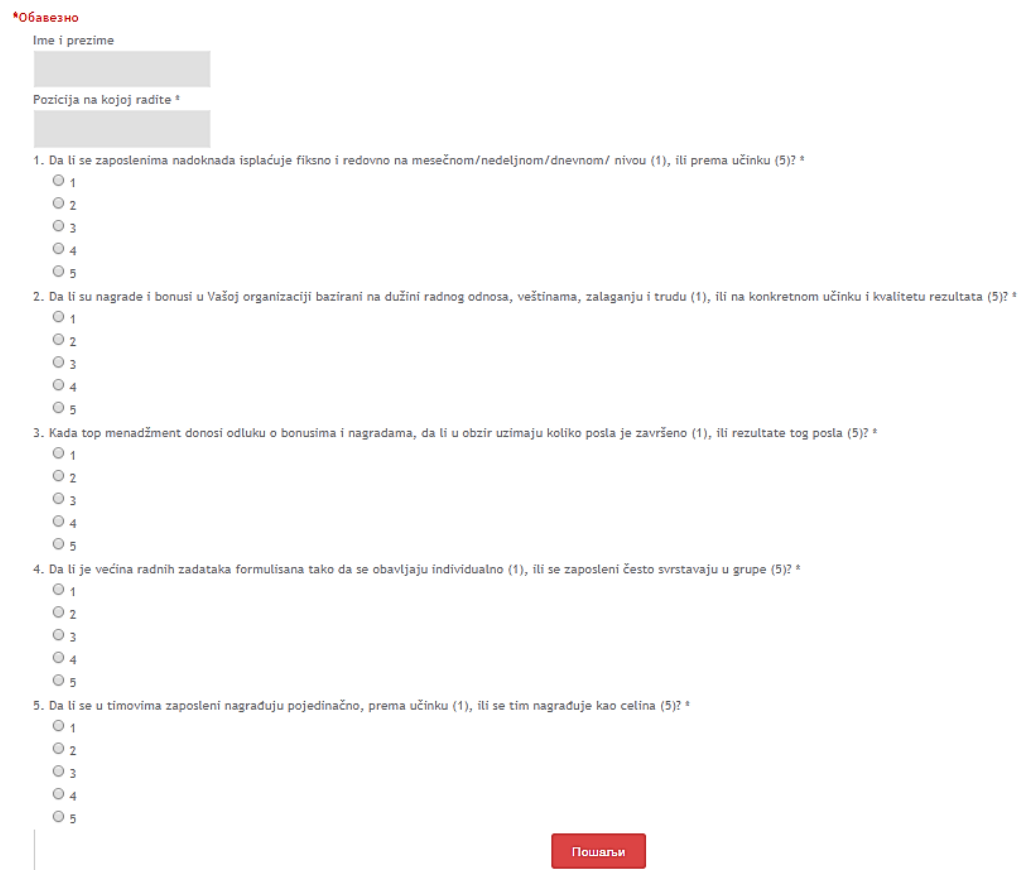

Slika 12 - Izgled ankete registrovanog korisnika - plaćena usluga

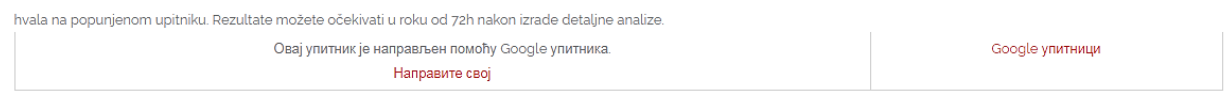

Slika 13 - Pozdravna poruka nakon završene ankete

Klijent prvo kontaktira agenciju i ugovara potrebne usluge koje želi. Nakon sastavljanja ponude agencija šalje predlog cene i plana sprovođenja, nakon čega klijent potvrđuje da li je saglasan sa predloženom ponudom. Klijent dobija link na email svakog zaposlenog (u formi www.its-consult.cf/Php/getinfoandlogin/?user=korisnik) preko koga pristupa platformi.

Link je unikatan i nije moguće pristupiti kao druga osoba datom linku zbog provere naloga i potvrde autentifikacije korisnika. To znači da ako neko pristupi linku a anketa sa linka nije njemu namenjena, neće mu biti dozvoljeno da je popuni. Takođe, potrebno je kreirati naloge za svakog zaposlenog kojeg je klijent naručilac naveo kao ispitanika da bi se omogućila što objektivnija analiza i sa manje manipulacija. Parametri za nalog svakog zaposlenog se šalju na mejl zaposlenog i time se sprečava moguća zloupotreba da jedna osoba dođe do informacija svih naloga i time naruši regularnost anketiranja.

Nakon odrađene ankete od strane svih zaposlenih, koja se može pratiti kroz sistem, pristupa se analizi odgovora. Analiza se radi na računaru od strane određenog zaposlenog ili više njih a konačni zaključci i rešenja se beleže u jedinstveni dokument za klijenta naručioca. Nakon izrade dokumenta, on se postavlja na server agencije i beleži u bazu podataka. 
O završetku analize se obaveštava klijent naručilac i u mejlu mu se šalje link kojem može pristupiti i preuzeti izveštaj. Dokumentu nije moguće pristupiti preko platforme već isključivo putem dobijenog linka koji će biti ograničenog vremenskog trajanja radi sigurnosti.

Ovim načinom je ubrzana komunikacija i dostavljanje dokumenata naručiocu usluga pogotovu ako uzimamo u obzir razdaljinu sedišta agencije i sedište klijenta. Ako se izveštaj šalje poštom to oduzima minimalno dva dana. U slučaju da se lično vrši dostavljanje dokumenata analize, to iziskuje dodatni trošak za prevoz, smeštaj ako je potreban i utrošeno vreme. Kako su kompanije u današnje vreme zasute raznim informacijama i vremenskim pritiskom na akcentu brzog donošenja odluka i poteza, elektronski način dostavljanja izveštaja predstavlja efikasniji metod. Takođe, ovim načinom je omogućeno klijentu da razmotri analizu onda kada je u mogućnosti bez ograničenog vremenskog trajanja sastanka u slučaju lične dostave dokumentacije i iznošenje zaključaka od strane konsultanta.

\section{Upotreba platforme u konkretnim biznis modelima (start up)}

Svaka organizacija je unikatan sistem sa svojim komponentama i nije moguće svaku organizaciju analizirati na isti način. Jedna od razlika je i tip poslovanja tj. da li se organizacija bavi uslužnom ili proizvodnom delatnošću.

Postoje dva načina, gledano sa stanovišta angažovanja resursa, kako se može izvršiti analiza organizacije:

1. Interno

2. Eksterno

Interna analiza podrazumeva da se analiza organizacije vrši unutar kompanije bez uplitanja treće strane (organizacije) u analizu.

Eksterna analiza podrazumeva da analizu vrši treća strana (organizacija) sertifikovana od strane ovlašćenog tela. Obično je to jedna od agencija za konsultantske usluge u oblasti analize poslovnih sistema.

U oba slučaja moguće je primeniti automatizaciju primenom odgovarajućeg softverskog rešenja, mada mnogo jednostavnije u sklopu interne analize. Kada se vrši eksterna analiza kompanije u tom slučaju imate manju mogućnost da utičete na automatizaciju procesa.

Glavno pitanje je zašto? Zašto bi organizacija plaćala dodatno i softversko rešenje za automatizaciju kada već plaća zaposlene ili u slučaju eksterne analize agenciju? Zašto automatizovati proces analize kada je potrebno da sve prikupljene informacije obradi čovek a ne računar, sobzirom da u pitanju nije softver veštačke inteligencije? Odgovor je jednostavan i skriva se pre svega u brzini i vremenu potrebnom za donošenje odluka.

Kao što je poznato, danas je donošenje relevantnih odluka na osnovu dobijenih informacija vrlo bitno, a sve informacije su podložne promeni u kratkom vremenskom roku. Ranije ste bili u mogućnosti da, recimo, donesete ključnu odluku na osnovu prikupljenih informacija u roku od 7 dana, danas je to možda 1 dan ili možda 1 sat u budućnosti. Činjenica je da je vremena danas vrlo malo i da ga treba što bolje iskoristiti.

Primena web platforme u svrhu automatizacije u analizi poslovnog sistema se ogleda u:

- Bržem i potencijalno efikasnijem donošenju odluka

- Ekološki prihvatljivo rešenje zbog manje potrošnje papira

- Veća kontrola regularnosti anketiranja

- Dostupnost u bilo koje doba dana 
Takođe, ova web platforma može imati i različitu primenu u zavisnosti od biznis modela kojem se primenjuje:

- Analiza unutar sopstvene organizacije

- Analiza partnerske organizacije

- Analiza konkurentske organizacije

- Analiza drugih organizacija kao samostalna konsultantska delatnost

Analiza unutar sopstvene organizacije se najčešće vrši eksterno od strane sertifikovane agencije koja pruža tražene usluge. Ujedno ovaj biznis model je osnovni biznis model u kom bi ova platforma imala veliki značaj. Njena efikasnost se ogleda u uštedi vremena za analizu i uštedu resursa (konkretno procesa štampe, papira i vremena) potrebnih za njeno obavljanje. U slučaju da nema adekvatno obučenih i kvalifikovanih zaposlenih u organizaciji za analizu poslovnih sistema to iziskuje i dodatni trošak obuke. Nakon završene obuke, na duže staze, kompanija može analizirati sopstveni sistem u kraćim odnosno češćim intervalima i tako pratiti stanje sistema i zadovoljstvo svojih zaposlenih. $\mathrm{Na}$ osnovu tih informacija moguće je unaprediti i sistem nagrađivanja, pohvala i priznanja uzimajući u obzir želje zaposlenih kao i usaglasiti planove sa ciljevima.

U slučaju angažovanja eksternih konsultanata postoji i problem iznošenja bitnih podataka osobi koja je van organizacije. U tom slučaju se obavezno potpisuje dokument o poverljivosti podataka kojim se regulišu prava i obaveze obe strane. Između ostalog, eksterni konsultant se obavezuje da podatke do kojih dođe prilikom vršenja svojih usluga čuva kao poslovnu tajnu i da ih neće zloupotrebiti zarad sticanja materijalne ili neke druge vrste lične koristi.

Ako se analiza radi internim snagama, tu imamo i korist koji se ogleda u razvoju zaposlenih. Ulaganjem u njihovo dodatno obrazovanje dobijamo kvalitetnije zaposlene a takođe smanjujemo troškove koje bi imali za angažovanje eksternog konsultanta.

Zaposleni koji su angažovani na unosu pitanja i analize odgovora, unose pitanja u bazu podataka i dodeljuju odgovarajuću anketu svakom od zaposlenih. Svaki zaposleni dobija link putem email-a preko kojeg pristupa platformi i svojoj odgovarajućoj formi. Da bi se sprečila zloupotreba i eventualna slučajnost greške koji korisnik je u pitanju, zahteva se ponovna autentifikacija korisnika. Korisnik unosi svoje parametre za logovanje koji se naknadno upoređuju sa podacima ankete i ako se podudaraju, zaposleni može pristupiti popunjavanju forme. Nakon završene ankete dobijaju poruku „zahvalnice“ i da su uspešno završili anketu.

Analiza partnerske kompanije može poslužiti kao pomoć pri donošenju odluka našeg partnera a nema već postojeći sistem preko koga bi mogao da vrši automatizovano izveštavanje. Takođe, ovim postupkom doprinosimo i zajedničkoj saradnji.

Ujedno, platforma se može iskoristiti i kao alat promocije unutar partnerske kompanije kao rešenje koje kasnije može da se komercijalizuje ill zadrži isključivo za internu upotrebu. Ovaj model se najčešće radi interno, od strane naših zaposlenih. U slučaju komercijalizacije oformilo bi se posebno odeljenje i po potrebi obučilo ili zaposlilo još nekoliko radnika. Takođe, biće potrebno pojačati tehnički tim s obzirom da se platforma zasniva na delimičnom kodiranju.

Analiza konkurentske organizacije može poslužiti za analizu konkurenata i predviđanja njihovih daljih poteza. Po ovoj metodi može se analizirati u kakvom je stanju konkurent i na osnovu njegovih budućih poteza videti da li će konkurenti napraviti grešku kod neke odluke. Ako je naprave organizacija može napraviti iskorak i preduhitriti konkurenta sa boljom ponudom, saradnjom ili nečim sličnim što našoj organizaciji može doneti prednost na tržištu u odnosu na njega. Za ovu metodu potrebno je posedovanje insajdera u konkurentskoj organizaciji i da se primeni metod benčmarkinga uz prateće SWOT i PEST(EL) analize. 
Takođe, analiza konkurentske organizacije može se vršiti na bazi javno dostupnih podataka i informacija iz agencije za privredne registre, javno dostupnih finansijskih izveštaja o poslovanju, ispitivanjem javnog mnjenja i drugim metodama i tehnikama.

Analiza drugih organizacija kao samostalna konsultantska delatnost se može upotrebiti za osnivanje konsultantske organizacije iz određenog startup-a ili da iz postojeće organizacije izdvojite još jedan sektor koji će se baviti konsultantskim uslugama. Ovakav model podrazumeva transformaciju organizacione strukture u slučaju da se koristi kao poseban sektor. Pre svega ovde se misli na dodatan broj zaposlenih, menadžera i finansijski izdatak koji se javlja. Prilikom izdvajanja sektora treba voditi računa i u kom sektoru firma posluje. Na primer, nije isto ako se firma bavi poslovima u oblasti informacionih tehnologija (uže definisano - na razvoju i implementaciji poslovnih sistema) ili se bavi ugostiteljstvom.

U navedenom primeru, informacione tehnologije su usko vezane za razvoj softvera poslovnih sistema samim tim imaju neko predznanje kako bi određena organizacija trebalo da funkcioniše, što nije slučaj baš sa npr. ugostiteljstvom. Istina je da oni u svojoj delatnosti bolje poznaju svoj posao ali da izdvoje poseban sektor da se pored ugostiteljstva bave i analizom može više da ih košta, uključujući i obuku, nego profit koji mogu ostvariti. Tu dolazimo i do marketinga koji u tom slučaju više ide u korist firme koja se bavi informacionim tehnologijama iz oblasti poslovnih sistema nego ugostiteljima.

Kao i svakoj organizaciji koja je počela od „nule“, startup kompanije ne mogu imati dovoljno finansija da bi uložili u sve potrebne resurse kako bi startovali ozbiljno na tržištu od samog starta. Iz tog razloga, start-up kompanije koje bi se bavile konsultantskim uslugama, sa potrebnim znanjem koje poseduju, mogu sebe istaći jednostavnom automatizacijom konsultantskih usluga primenom ove ili slične platforme.

Time dobijaju moćan alat u svojoj oblasti rada po relativno pristupačnoj ceni u zavisnosti od iskustva tima i njegovog sastava. S obzirom da su mladi sve više uključeni u oblast informacionih tehnologija bilo kojim poslom da se bave i da je učenje programiranja sve dostupnije na internetu, mogu to iskoristiti uz minimalna ulaganja da bi oformili platformu.

Inovativni projekti obično imaju nepisano pravilo da su visoko rizični. U većini slučajeva investiranje u nove kompanije (startup-ove) potpadaju pod prethodnu definiciju ali kada govorimo o inovacijama kojih nema na tržištu i koriste se po prvi put, pored toga što sadrže visok rizik, nekada vredi usuditi se finansirati ih (Popkova \& Ostrovskaya, 2019).

Kao što je prethodno opisano kako platforma funkcioniše tako je moguće da startup organizacija prilagodi platformu određenom komercijalnom rešenju koje razvije i objavi na internetu predstavljajući sebe ispred ostalih. Zainteresovani klijenti koji posete web platformu mogu isprobati funkcionisanje samog sistema odmah, odgovorom na jednu od ponuđenih anketa. Rezultate će dobiti odmah nakon završetka.

Takva analiza je okvirna i ne predstavlja nužno tačnost. Ako se zainteresovanom klijentu svidi način na koji je vršena analiza tj. pitanja koja su postavljena u svrhu analize, može kontaktirati organizaciju i dogovoriti se za detaljniju uslugu konsultanta takođe putem web platforme uz odgovarajuću novčanu naknadu.

Još jedna od opcija kod startup-ova bi mogla biti da startup-ovi koji se bavi razvojem softvera (programiranjem) mogu proizvoditi ovakav tip softvera koji može biti sačinjen integracijom već gotovih rešenja sa dosta manje kodiranja. Rešenje bi moglo biti vrlo profi- 
tabilno sa relativno malim ulaganjima ili bi moglo da uvede malo racionalniju ponudu na tržištu tako što bi rešenje bilo ponuđeno po pristupačnijim cenama. Time bi konkurencija bila poljuljana i morala bi da prihvati automatizaciju kao svakodnevicu ili rizikuje poziciju na tržištu. Naravno, trenutno u ovom trenutku to ne izgleda previše bitno ali u skorijoj budućnosti itekako će biti.

\section{Zaključak}

Posebna korist primene predstavljene veb platforme jeste u startup organizacijama. $S$ obzirom da je trošak izrade aplikacije moguće smanjiti na minimum, zbog sve veće dostupnosti besplatnog materijala za učenje putem interneta, tim koji osniva startup može sam da kreira platformu i prilagodi svojim potrebama. Pored toga što ovim postupkom stiče konkurentsku prednost, privlači i potencijalne investitore za razvoj svog rešenja i njegovu širu primenu na tržištu. Dodatni plus za smanjenje troškova jeste ako kompanija ima dovoljan broj raspoloživih zaposlenih i tim programera kojima može izvršiti preraspodelu radnih zadataka uz odgovarajuće korigovanje zarade.

\section{Literatura}

[1] Burton, R. M., Obel, B., \& DeSanctis, G. (2011). Organizational design. New York: Cambridge University Press.

[2] Meisen, P. (2016). Analyzing Time Interval Data: Introducing an Information System for Time Interval Data Analysis. Aachen, Germany: Springer Fachmedien Wiesbaden $\mathrm{GmbH}$.

[3] Pavlović, N. (2019). Preuzeto Februar 13, 2019 sa ITS konsultant: www.its-consult.cf

[4] Pokorni, S., \& Radić, G. (2013). Informacione i interent tehnologije. Beograd: Visoka škola strukovnih studija za informacione tehnologije, ITS - Beograd.

[5] Popkova, E. G., \& Ostrovskaya, V. N. (2019). Perspectives on the Use of New Information and Communication Technology (ICT) in the Modern Economy. USA: Springer International Publishing AG.

[6] Ranković, M., \& Ilić, M. (2018). Upravljanje projektima. Beograd: Visoka škola strukovnih studija za informacione tehnologije, ITS - Beograd.

[7] Sajfet, Z. (2006). Organizacija poslovnih sistema. Zrenjanin: Tehnički fakultet „Mihajlo Pupin“, Zrenjanin, Univerziteta u Novom Sadu.

[8] Zohuri, B., \& Moghaddam, M. (2017). Business Resilience System (BRS): Driven Through Boolean, Fuzzy Logics and Cloud Computation. Springer International Publishing AG 2017. 